\title{
Identifikasi Jenis dan Tingkat Serangan Hama Pada Pembibitan Tanaman Kelapa Sawit (Elaeis guineensi Jacq) di PT. Sentosa Kalimantan Jaya, Kabupaten Berau Provinsi Kalimantan Timur
}

\section{Identification of Types and Levels of Pest Attacks on Oil Palm Seedlings (Elaeis guineensi Jacq) at PT. Sentosa Kalimantan Jaya, Berau District East Kalimantan Province}

\author{
Andi Nur Cahya ${ }^{1}$, lin Arsensi ${ }^{2}$, Purwati ${ }^{2}$ \\ 1 Alumni Program Studi Agroteknologi, Fakultas Pertanian, Universitas Widya Gama Mahakam Jl. KH. Wahid \\ Hasyim, Sempaja, Samarinda, Kalimantan Timur, Indonesia \\ 2 Tenaga Pendidik Program Studi Agroteknologi, Fakultas Pertanian, Universitas Widya Gama Mahakam Jl. KH. \\ Wahid Hasyim, Sempaja, Samarinda, Kalimantan Timur, Indonesia
}

Email : andinurcahya339@gmail.com, ienarsensi@yahoo.com, purwatiuwgm@gmail.com

Diterima : 4 April 2019 Disetujui : 17 Juni 2019

\begin{abstract}
Identification of Types and Levels of Pests Attack on Palm Plantation Seedlings (Elaeis guineensis Jacq) at PT. Sentosa Kalimantan Jaya, Berau District East Kalimantan Province. Under the guidance of Iin Arsensi and Purwati. This study aims to determine the types of pests that attack oil palm seedlings, the frequency and intensity of oil palm pest attack on the Main Nursery stage nursery. The research was arranged in Survey method, determining 5 research plots in one block diagonally by marking on each plot with plastic marker of seeds, so obtained 15 research plots contained in 3 block that is block J, I and D. Each research plot consists of 30 Oil palm seedlings so that the number of observed 450 seeds of oil palm. The results showed that the types of pests that attack the oil palm seedlings in Main Nursery are Tungau (Tetranychus piercei), Adoretus compressus Beetle, and Locusta migratoria manilensis (Locusta migratoria manilensis); Block Frequency A pest attack in the category of minor attacks is $51.33 \%$, 24\% attack, while the intensity of pest attacks is a mild attack category; Frequency of Block I attack of pests in light attack category is 49,33\%, moderate attack 37,33\%, heavy attack $2 \%$, while intensity of pest attack moderate attack category; Frequency of Block D attack of pest in light attack category is 41,3\%, moderate attack 41,3\%, severe attack 7,3\%, while intensity of pest attack moderate attack category;
\end{abstract}

Keywords: Oil palm, identification of types and levels of pest attacks

\section{PENDAHULUAN}

Kelapa sawit (Elaeis guineensis Jacq) merupakan salah satu tanaman penghasil minyak nabati yang sangat penting. Dewasa ini, kelapa sawit tumbuh sebagai tanaman liar (hutan), setengah liar, dan sebagai tanaman budidaya yang terbesar di berbagai negara beriklim tropis bahkan mendekati subtropis di Asia, Amerika Selatan, dan Afrika (Setyamidjaja., 2006).

Dewasa ini, komoditas kelapa sawit merupakan komoditas perdagangan yang sangat menjanjikan. Pada masa depan minyak sawit diyakini tidak hanya mampu menghasilkan berbagai hasil industri hilir yang dibutuhkan manusia seperti minyak goreng, mentega, sabun, kosmetik, dan lain - lain, tetapi juga dapat menjadi substitusi bahan bakar minyak yang saat ini sebagian besar dipenuhi dengan minyak bumi. Apalagi, minyak bumi yang sumbernya tidak dapat diperbaharui, minyak sawit merupakan sumber bahan minyak nabati yang dapat diperbaharui, sehingga tidak akan pernah habis selama manusia membudidayakan secara komersial (Setyamidjaja., 2006).

Tanaman kelapa sawit tergolong tanaman kuat, walaupun begitu tanaman ini juga tidak luput dari serangan hama dan penyakit, baik yang kurang membahayakan maupun yang membahayakan. Sebagian besar hama yang menyerang adalah golongan insekta atau serangga, sedangkan penyakit yang menyerang tanaman kelapa sawit umumnya disebabkan oleh jamur, bakteri, dan virus (Kiswanto dkk., 2010).

Beberapa hama yang biasa menyerang bibit kelapa sawit pada tahap main nursery diantaranya adalah uret, kumbang malam (Apogonia sp), ulat kantong, kutu daun (Aphids), ulat api (Setora nitens), dan belalang (Locusta migratoria malinensis). (Darmosarkoro dkk., 2010). 
Produktivitas kelapa sawit sangat bergantung kepada penyiapan bibit yang pertumbuhannya baik, bibit yang baik diperoleh dengan pemeliharaan yang intensif seperti media, penyiraman, pemupukan, pengendalian hama dan penyakit. Oleh karena ini perlu dilakukan identifikasi serangan hama sedini mungkin agar dapat dikendalikan dengan baik. Jenis hama yang sering menyerang bibit kelapa sawit adalah kumbang malam yang memakan daun dengan cara melobangi daun dari bagian tengah daun, tungau dengan membuat daun klorosis berwarna hitam yang mengganggu proses fotosintesis, belalang dengan memakan daun pada bagian sisi pinggir daun, dan ulat daun dengan memakan bagian sisi pinggir daun, dimana serangan hama tersebut dapat menyebabkan kerusakan dan menurunnya mutu bibit kelapa sawit yang akan ditanam ke lapangan.

Berdasarkan uraian diatas maka perlu dilakukan penelitian identifikasi jenis dan tingkat serangan hama pada pembibitan tanaman kelapa sawit (Elaeis guineensis Jacq) di PT Sentosa Kalimantan Jaya, Kabupaten Berau, Provinsi Kalimantan Timur.

\section{HASIL DAN PEMBAHASAN}

\section{Jenis Hama dan Jumlah Daun Terserang.}

Data hasil pengamatan lapangan terhadap tanaman yang berada pada blok $\mathrm{J}$ menunjukkan bahwa telah ditemukan 8 ekor hama belalang, 49 ekor hama kumbang Adoretus, dan 241 daun yang terserang hama tungau (Tabel 1). Dari data tersebut dapat diketahui juga bahwa terdapat rata-rata jumlah daun yang terserang

\section{BAHAN DAN METODE}

Penelitian ini dilaksanakan di Pembibitan Main Nursery PT. Sentosa Kalimantan Jaya, yang berada di lokasi Mutiara Estate, daerah Kampung. Tanjung Batu, Kecamatan Pulau Derawan, Kabupaten Berau, Provinsi Kalimantan Timur, Waktu penelitian adalah satu bulan yaitu mulai bulan Desember 2016 sampai dengan bulan Januari 2017.

Tanaman yang dijadikan objek penelitian adalah bibit yang berlokasi di main nursery (pembibitan utama), jumlah blok yang dijadikan objek yaitu tiga blok antara lain Blok J, I, dan D. Tehnik penentuan sampel yaitu dengan sistem Sampling Purposive, dimana pada setiap blok ditentukan 5 plot penelitian sebagai ulangan, Penentuan 5 plot penelitian dalam satu blok secara diagonal dengan memberi tanda pada setiap plotnya dengan plastik penanda bibit sehingga diperoleh 15 plot penelitian yang terdapat di 3 blok yaitu blok J, I dan D. Setiap plot penelitian terdiri atas 30 bibit tanaman dengan demikan tanaman yang diamati sebanyak 450 bibit tanaman.

Tabel 1. Jenis dan Jumlah Hama yang Menyerang Tanaman Kelapa Sawit pada Pembibitan Blok J.

\begin{tabular}{ccccc}
\hline Plot & \multicolumn{3}{c}{ Jenis dan jumlah hama } & Jumlah Daun \\
\cline { 2 - 4 } & Belalang & $\begin{array}{c}\text { Kumbang } \\
\text { Adoretus }\end{array}$ & Tungau & 194 \\
\hline 1 & 0 & 10 & 59 & 210 \\
2 & 1 & 7 & 52 & 167 \\
3 & 1 & 13 & 50 & 177 \\
4 & 3 & 7 & 44 & 142 \\
5 & 2 & 12 & 36 & $\mathbf{8 9 0}$ \\
\hline Jumlah & $\mathbf{8}$ & $\mathbf{4 9}$ & $\mathbf{2 4 1}$ & $\mathbf{5 , 9}$ \\
\hline Rata - rata & $\mathbf{0 , 0 5}$ & $\mathbf{0 , 3 2}$ & $\mathbf{1 , 6}$ & \\
\hline
\end{tabular}

dalam tiap pokok sampel yaitu 6 pelepah daun. Khusus untuk serangan hama tungau yaitu pada setiap pokok ditemukan daun yang terserang sebanyak 2 pelepah daun.

Jenis dan Jumlah hama yang menyerang tanaman kelapa sawit pada pembibitan, blok J dapat dilihat pada Tabel 1.
Data hasil pengamatan lapangan terhadap tanaman yang berada pada blok I menunjukkan bahwa telah ditemukan 11 ekor hama belalang, 59 ekor hama kumbang Adoretus, dan 226 daun yang terserang hama tungau (Tabel 2). Dari data tersebut dapat diketahui juga bahwa terdapat rata rata 7 daun yang terserang pada tiap pokok. Khusus untuk serangan hama 
tungau yaitu pada setiap pokok ditemukan daun yang terserang sebanyak 2 pelepah daun. Jenis dan Jumlah hama yang menyerang tanaman kelapa sawit pada pembibitan, blok I dapat dilihat pada Tabel 2.

Tabel 2. Jenis dan Jumlah Hama yang Menyerang Tanaman Kelapa Sawit pada Pembibitan pada Blok I

\begin{tabular}{ccccc}
\hline Plot & \multicolumn{3}{c}{ Jenis Hama } & Jumlah Daun \\
\cline { 2 - 4 } & Belalang & $\begin{array}{c}\text { Kumbang } \\
\text { Adoretus }\end{array}$ & Tungau & Terserang \\
\hline 1 & 2 & 8 & 44 & 196 \\
2 & 1 & 11 & 53 & 248 \\
3 & 2 & 13 & 46 & 209 \\
4 & 2 & 17 & 48 & 206 \\
5 & 4 & 10 & 35 & 143 \\
\hline Jumlah & $\mathbf{1 1}$ & $\mathbf{5 9}$ & $\mathbf{2 2 6}$ & $\mathbf{1 . 0 0 1}$ \\
\hline Rata - rata & $\mathbf{0 , 0 7}$ & $\mathbf{0 , 3 9}$ & $\mathbf{1 , 5}$ & $\mathbf{6 , 6 7}$ \\
\hline
\end{tabular}

Data hasil pengamatan lapangan terhadap tanaman yang berada pada blok D menunjukkan bahwa telah ditemukan 10 ekor hama belalang, 57 ekor hama kumbang Adoretus, dan 214 daun yang terserang hama tungau (Tabel 3). Dari data tersebut dapat diketahui juga bahwa terdapat rata rata 6 daun yang terserang pada tiap pokok.
Khusus untuk serangan hama tungau yaitu pada setiap pokok ditemukan daun yang terserang sebanyak 2 pelepah daun.

Jenis dan Jumlah hama yang menyerang tanaman kelapa sawit pada pembibitan, blok $\mathrm{D}$ dapat dilihat pada Tabel 3 .

Tabel 3. Hasil Pengamatan Jenis Hama yang Menyerang Tanaman Kelapa Sawit pada Pembibitan pada Blok D

\begin{tabular}{ccccc}
\hline \multirow{2}{*}{ Plot } & \multicolumn{3}{c}{ Jenis Hama } & Jumlah Daun \\
\cline { 2 - 4 } & Belalang & $\begin{array}{c}\text { Kumbang } \\
\text { Adoretus }\end{array}$ & Tungau & Terserang \\
\hline 1 & 3 & 14 & 48 & 164 \\
2 & 3 & 12 & 52 & 189 \\
3 & 1 & 8 & 47 & 197 \\
4 & 1 & 11 & 37 & 193 \\
5 & 2 & 12 & 30 & 163 \\
\hline Jumlah & $\mathbf{1 0}$ & $\mathbf{5 7}$ & $\mathbf{2 1 4}$ & $\mathbf{9 0 6}$ \\
\hline Rata - rata & $\mathbf{0 , 0 6}$ & $\mathbf{0 , 3 8}$ & $\mathbf{1 , 4}$ & $\mathbf{6 , 0 4}$ \\
\hline
\end{tabular}

\section{Frekuensi dan Intensitas Serangan Hama}

Hasil analisis frekuensi dan intensitas serangan hama pada tanaman kelapa sawit di pembibitan pada blok $\mathrm{J}$ menunjukkan bahwa bibit dengan kondisi sehat $24,66 \%$, bibita dengan kategori serangan ringan yaitu 51,33\%, kategori sedang $24,00 \%$, kategori serangan berat dan bibit mati akibat serang adalah 0 . Frekuensi dan intensitas serangan hama pada tanaman kelapa sawit di pembibitan pada blok J termasuk dalam kategori serangan ringan.

Hasil analisis frekuensi dan intesitas serangan hama di pembibitan pada blok $\mathrm{J}$ sebagimana disajikan pada Tabel 4. Hasil analisis frekuensi dan intensitas serangan hama pada tanaman kelapa sawit di pembibitan pada blok I menunjukkan bahwa bibit dengan kondisi sehat $11,3 \%$, bibit dengan kategori serangan ringan yaitu 49,33\%, kategori sedang $37,33 \%$, kategori serangan berat $2 \%$ dan bibit mati akibat serang adalah 0 . Frekuensi dan intensitas serangan hama pada tanaman kelapa sawit di pembibitan pada blok I termasuk dalam kategori serangan sedang.

Hasil analisis frekuensi dan intesitas serangan hama di pembibitan pada blok I sebagiamana disajikan pada Tabel 5.

Hasil analisis frekuensi dan intensitas serangan hama pada tanaman kelapa sawit di pembibitan pada blok I menunjukkan bahwa bibit dengan kondisi sehat $10 \%$, bibit dengan 
kategori serangan ringan yaitu $41,3 \%$, kategori sedang $41,3 \%$, kategori serangan berat 7,3\% dan bibit mati akibat serang adalah 0 . Frekuensi dan intensitas serangan hama pada tanaman kelapa sawit di pembibitan pada blok D termasuk dalam kategori serangan sedang. Hasil analisis frekuensi dan intesitas serangan hama di pembibitan pada blok D sebagimana disajikan pada Tabel 6.

Tabel 4. Hasil Analisis Frekuensi dan Intensitas Serangan Hama Tanaman Kelapa Sawit pada Pembibitan pada Blok J

\begin{tabular}{|c|c|c|c|c|c|c|}
\hline \multirow[b]{2}{*}{ Plot } & \multicolumn{5}{|c|}{ Kondisi Bibit Kelapa Sawit } & \multirow[b]{2}{*}{ Total Bibi } \\
\hline & Bibit Sehat & $\begin{array}{c}\text { Serangan } \\
\text { Ringan }\end{array}$ & $\begin{array}{c}\text { Serangan } \\
\text { Sedang }\end{array}$ & Serangan Berat & $\begin{array}{l}\text { Bibit } \\
\text { Mati }\end{array}$ & \\
\hline 1 & 5 & 19 & 6 & 0 & 0 & 30 \\
\hline 2 & 6 & 9 & 15 & 0 & 0 & 30 \\
\hline 3 & 9 & 14 & 7 & 0 & 0 & 30 \\
\hline 4 & 6 & 19 & 5 & 0 & 0 & 30 \\
\hline 5 & 11 & 16 & 3 & 0 & 0 & 30 \\
\hline Jumlah Bibit & 37 & 77 & 36 & $\mathbf{0}$ & $\mathbf{0}$ & 150 \\
\hline Frekuensi & $24,66 \%$ & $\mathbf{5 1 , 3 3 \%}$ & $24,00 \%$ & $\mathbf{0}$ & $\mathbf{0}$ & $\mathbf{0}$ \\
\hline Intensitas & & & $24,83 \%$ & & & Ringan \\
\hline
\end{tabular}

Tabel 5. Hasil Analisis Frekuensi dan Intensitas Serangan Hama Tanaman Kelapa Sawit pada Pembibitan pada Blok I

\begin{tabular}{ccccccc}
\hline \multirow{2}{*}{ Plot } & \multicolumn{7}{c}{ Kondisi Bibit Kelapa Sawit } & \multirow{2}{*}{ Total Bibit } \\
\cline { 2 - 5 } & Bibit Sehat & $\begin{array}{c}\text { Serangan } \\
\text { Ringan }\end{array}$ & $\begin{array}{c}\text { Serangan } \\
\text { Sedang }\end{array}$ & $\begin{array}{c}\text { Serangan } \\
\text { Berat }\end{array}$ & $\begin{array}{c}\text { Bibit } \\
\text { Mati }\end{array}$ & \\
\hline 1 & 4 & 17 & 9 & 0 & 0 & 30 \\
2 & 0 & 12 & 15 & 3 & 0 & 30 \\
3 & 2 & 20 & 8 & 0 & 0 & 30 \\
4 & 1 & 10 & 19 & 0 & 0 & 30 \\
5 & 10 & 15 & 5 & 0 & 0 & 30 \\
Jumlah Bibit & $\mathbf{1 7}$ & $\mathbf{7 4}$ & $\mathbf{5 6}$ & $\mathbf{3}$ & $\mathbf{0}$ & $\mathbf{1 5 0}$ \\
\hline Frekuensi & $\mathbf{1 1 , 3 \%}$ & $\mathbf{4 9 , 3 3 \%}$ & $\mathbf{3 7 , 3 3 \%}$ & $\mathbf{2 \%}$ & $\mathbf{0}$ & $\mathbf{0}$ \\
\hline Intensitas & \multicolumn{7}{c}{$\mathbf{3 2 , 5 \%}$} & & & Sedang \\
\hline
\end{tabular}

Tabel 6. Hasil Analisis Frekuensi dan Intensitas Serangan Hama Tanaman Kelapa Sawit pada Pembibitan pada Blok D.

\begin{tabular}{ccccccc}
\hline \multirow{2}{*}{ Plot } & \multicolumn{7}{c}{ Kondisi Bibit Kelapa Sawit } & \multirow{2}{*}{\begin{tabular}{c} 
Total Bibit \\
\cline { 2 - 6 }
\end{tabular}} & $\begin{array}{c}\text { Bibit } \\
\text { Sehat }\end{array}$ & $\begin{array}{c}\text { Serangan } \\
\text { Ringan }\end{array}$ & $\begin{array}{c}\text { Serangan } \\
\text { Sedang }\end{array}$ & Serangan Berat & $\begin{array}{c}\text { Bibit } \\
\text { Mati }\end{array}$ & \\
\hline 1 & 6 & 18 & 6 & 0 & 0 & 30 \\
2 & 3 & 15 & 12 & 0 & 0 & 30 \\
3 & 0 & 7 & 19 & 4 & 0 & 30 \\
4 & 0 & 3 & 22 & 5 & 0 & 30 \\
5 & 6 & 19 & 3 & 2 & 0 & 30 \\
Jumlah Bibit & $\mathbf{1 5}$ & $\mathbf{6 2}$ & $\mathbf{6 2}$ & $\mathbf{1 1}$ & $\mathbf{0}$ & $\mathbf{1 5 0}$ \\
\hline Frekuensi & $\mathbf{1 0 \%}$ & $\mathbf{4 1 , 3 \%}$ & $\mathbf{4 1 , 3 \%}$ & $\mathbf{7 , 3 \%}$ & $\mathbf{0}$ & $\mathbf{0}$ \\
\hline Intensitas & & $\mathbf{3 6 , 5 \%}$ & & & Sedang \\
\hline
\end{tabular}

\section{Jenis Hama Pada Pembibitan Main Nursery Kelapa Sawit}

Hasil penelitian ditemukan beberapa jenis hama yang menyerang bibit kelapa sawit di main nursery yaitu hama Tungau (Tetranychus piercei),
Kumbang Adoretus compressus, dan Belalang (Locusta migratoria manilensis), seperti dapat dilihat pada gambar 1, 2, dan 3 . 


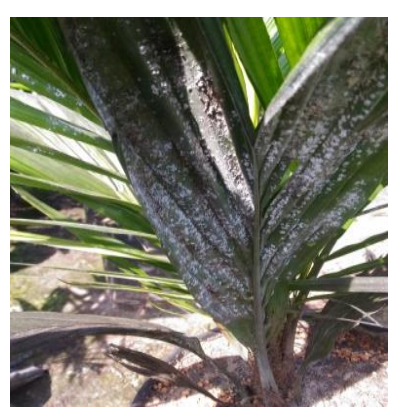

๑

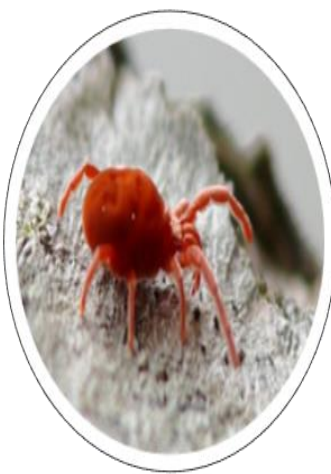

[5

Gambar $1:$ a). Gejala serangan hama tungau pada bagian bawah pelepah daun bibit kelapa sawit; b). Insert : Hama tungau (Tetranychus piercei).

Hama Tungau : hama jenis tungau menyerang pada bagian bawah daun, dengan gejala adanya bercak seperti tepung putih pada bagian bawah daun bibit kelapa sawit, dan menimbulkan warna bercak hitam pada bagian atas permukaan daun, serangan hama ini

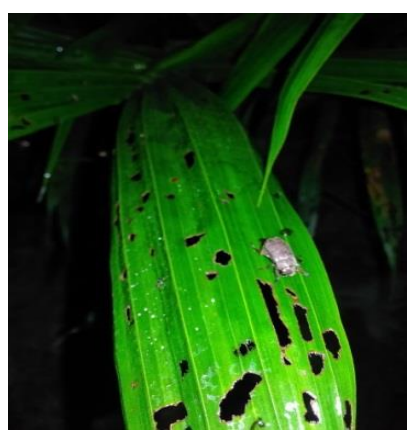

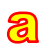

menyebabkan terhambatnya proses fotosintesis pada daun bibit kelapa sawit, secara umum serangan tungau merah dapat menyebabkan perubahan morfologi dan biokimia daun, serta komposisi buah. (Pramudianto dan Kurnia Pramita Sari., 2016)

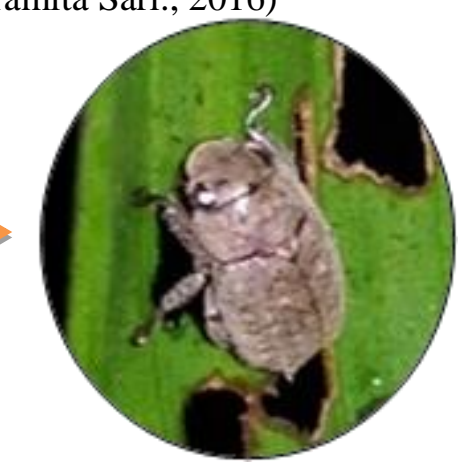

[5

Gambar 2 : a). Gejala serangan Kumbang Adoretus sp; b). Insert : Kumbang Adoretus compressus.

Hama Kumbang Adoretus : hama kumbang Adoretus, menyerang bibit kelapa sawit pada malam hari, tanda serangannya adalah dengan melubangi bagian tengah daun dengan lebar lubang kurang dari $1 \mathrm{~cm}$ pada awal serangan sehingga daun rusak pada bagian tengah daun. Dampak serangannya dapat

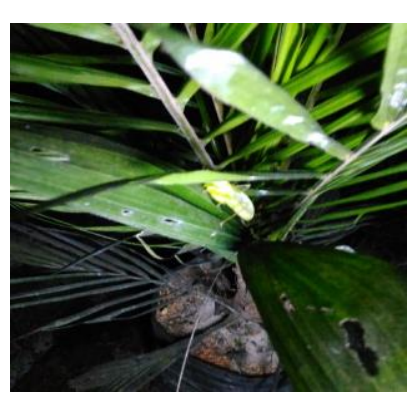

ฉ merusak mutu bibit kelapa sawit. Helaian daun berlubang - lubang, diatas daun sering ditemukan kotoran - kotoran kumbang, daun yang terserang akan tampak mengering dan secara umum pertumbuhan tanaman lebih kurus dan merana.( Yan Fauzi dkk., 2007)

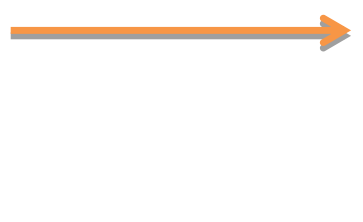

Gambar 3 : a). Belalang yang ditemukan pada daun bibit kelapa sawit; b). Insert Belalang (Locusta migratoria)

manilensis
mambar 3 : a). Belalang yang ditemukan pada daun bibit kelapa sawit, b). Insert Belalang (Locusta migratoria)

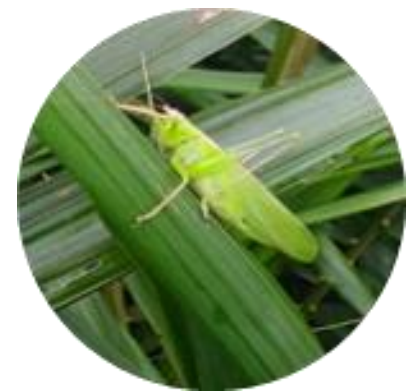

๒ 
Hama Belalang : hama jenis ini ditemukan tidak berkelompok atau baru ditemukan secara individual pada setiap pokok bibit kelapa sawit, ciri serangan belalang adalah rusaknya daun bibit kelapa sawit pada bagian pinggir daun. Apabila serangan parah atau jumlah belalang menyerang dalam skala kelompok maka bisa menghabiskan seluruh daun

\section{Hama Dominan di Pembibitan Main Nursery}

Dari ketiga jenis hama yang menyerang pembibitan main nursery yang paling dominan menimbulkan kerusakan daun pada bibit adalah hama tungau, serangan hama ini terdapat pada setiap blok pengamatan, dengan rata - rata 2 pelepah daun yang rusak, sedangkan hama kumbang Adoretus tingkat serangan masih kategori serangan ringan, hanya ditemukan 2 sampai 3 ekor kumbang pada setiap pokok bibit kelapa sawit, Menurut Susanto dkk (2010) ambang batas serangan sedang dan berat hama kumbang Adoretus adalah bila ditemukan sekitar 7 sampai 10 ekor

\section{Pengaruh Curah Hujan Terhadap Perkembangan Hama Tungau.}

Dari pengamatan dilapangan menunjukkan bahwa populasi tungau berfluktuasi sepanjang tahun. Secara umum populasi tertinggi terjadi pada bulan Agustus yang sangat kering, sedangkan tingkat populasi terendah terjadi pada bulan Oktober dan November yang sangat basah. Rendahnya populasi tungau pada musim penghujan diduga karena pengaruh mekanis dari curah hujan (Santoso dkk., 2014).

\section{KESIMPULAN}

1. Jenis Hama yang menyerang bibit kelapa sawit di Main Nursery adalah Tungau (Tetranychus piercei), Kumbang Adoretus compressus, dan hama Belalang (Locusta migratoria manilensis);

2. Frekuensi Blok J serangan hama pada kategori serangan ringan adalah $51,33 \%$, serangan sedang $24 \%$, sedangkan Intensitas serangan hama kategori serangan ringan;

3. Frekuensi Blok I serangan hama pada kategori serangan ringan adalah $49,33 \%$, serangan sedang $37,33 \%$, serangan berat $2 \%$, sedangkan pada satu pelepah sehingga sangat merusak bibit kelapa sawit. Serangan hama belalang sangat mirip dengan serangan hama Apogonia SP yaitu memakan atau mengerat daun pada bagian samping daun yang beraktivitas pada malam hari, tetapi pada saat penelitian tidak ditemukan Kumbang malam (Apogonia).

kumbang per pokok yang menyerang bibit kelapa sawit, hama yang menyerang bibitan main nursery juga terdapat hama belalang, tingkat serangan belalang termasuk dalam ketegori serangan ringan dan tidak berbahaya, karena rata - rata dalam dalam 1 blok pengamatan hanya ditemukan sekitar 8 sampai 11 ekor belalang secara terpisah, hal ini sesuai dengan pendapat Susanto (2010) bahwa ambang batas serangan sedang dan berat belalang adalah jika ditemukan serangan belalang secara berkelompok.

Pada saat penelitian bulan Desember 2016 terjadi masa kemarau di daerah Berau terutama didaerah penelitian di PT. Sentosa Kalimantan Jaya di Pembibitan Main nursery, hal ini berdampak dengan meningkatnya serangan hama Tungau yang menyerang daun bibit kelapa sawit yang diamati pada tingkatan umur bibit 16, 17, dan 18 bulan, serangan hama Tungau berkurang pada saat pertengahan dan akhir bulan Januari 2017 disaat mulainya musim hujan di daerah penelitian.

Intensitas serangan hama kategori serangan Sedang;

4. Frekuensi Blok D serangan hama pada kategori serangan ringan adalah $41,3 \%$, serangan sedang $41,3 \%$, serangan berat $7,3 \%$, sedangkan Intensitas serangan hama kategori serangan Sedang;

5. Dari tiga blok diatas, serangan hama paling dominan adalah hama Tungau karena menyerang hampir seluruh daun bibit. 


\section{DAFTAR PUSTAKA}

Allorerung, D; Syakir, M; Poeloengan, Z; Syafaruddin; Rumini, W. 2010. Budidaya Kelapa Sawit. Aska Media, Bogor.

Arsensi, I. 2015. Identifikasi penyakit pada Eucalyptus pellita F. Muell di PT. Surya Hutan Jaya, Sebulu (Disertasi), Program Studi Doktor Ilmu Kehutanan, Program Pasca Sarjana, Fakultas Kehutanan, Universitas Mulawarman, Samarinda.

Darmosarkoro W; Akiyat; Sugiyono; Sutarta E.S; 2010.Pembibitan Kelapa Sawit, Bagaimana Memperoleh Bibit Yang Jagur, PPKS, Medan.

Fauzi, Y; Widyastuti, Y.E; Satyawibawa, I; Hartono, R; 2007. Kelapa Sawit : Budidaya, Pemanfaatan Hasil dan Limbah, Analisis Usaha dan Pemasaran, Penebar Swadaya, Jakarta.

Kiswanto; Purwanta, J.H; Wijayanto, B. 2010.Teknologi Budidaya Kelapa Sawit, Balai Besar Pengkajian dan Pengembangan Teknologi Pertanian. Seri Buku Inovasi, Bogor.
Pramudianto; Kurnia Pramita Sari; 2016. Tungau Merah (Tetranychus Urticea Koch) Pada Tanaman Ubikayu dan Cara Pengendaliannya. Buletin Palawija Vol.14 No. 1 : 36 - 48 (Mei 2016)

Santoso S; Rauf, A; Gultom N.M; Karmawati E; Rumini W; 2014. Biologi dan Kelimpahan Tungau Merah (Tetranycus sp) pada dua kultivar jarak pagar. Jurnal Entomologi Indonesia, April 2014 Vol 11, No 1, 34 - 42.

Setyamidjaja D; 2006. Seri Budidaya Kelapa Sawit, Tehnik Budidaya, Panen, Pengolahan, Kanisius. Yogyakarta.

Sukamto ITN. 2011.58 Kiat Meningkatkan Produktivitas Dan Mutu Kelapa Sawit, Penebar Swadaya, Jakarta, $84 \mathrm{~h}$.

Susanto A; Purba, R.Y; Prasetyo, A.E; 2010. Seri Buku Pintar Hama dan Penyakit Kelapa Sawit, Vol.01, PPKS, Medan.

Purba, R.Y; Susanto A; Prawirosukarto S;2005. Buku 1. Hama Serangga pada Kelapa Sawit, Pusat Penelitian Kelapa Sawit, Medan. 